\title{
Seeking Rights from the Left: Gender, Sexuality, and the Latin American Pink Tide
}

\author{
Elisabeth Jay Friedman (editor). Durham, N.C.: Duke University \\ Press, 2018 (ISBN 978-1-4780-0260-4)
}

\author{
Adriana Novoa \\ University of South Florida, Tampa, FL, USA; Email: ainovoa@usf.edu
}

Sonia Alvarez, in the afterword of this book, correctly characterizes it as an "unprecedented, richly detailed collection" of essays (306) that enable us to examine a period in which center-left governments provided an alternative to the neoliberal wave that left nations impoverished, with a more inequality and corruption, by the end of the twentieth century. The Left's resurgence renewed coalitions, and its political form was for the most part defined as populist, following Ernesto Laclau's interpretation (Laclau 2005). In terms of gender and sexuality, the hope that this Pink Tide generated at the beginning of the twenty-first century was based on the actions of militant progressive forces that included women's, feminist, and LGBT organizations, which in some cases, like Argentina, led to the granting of rights for trans citizens and a new conception of identity and inclusiveness.

The elections of the early 2000s politicized gender and sexuality for the first time through the introduction of policies dealing with women's work, gender identity, and gay marriage. The integration of gender and sexuality in the political debate led to a backlash that was one of the factors in the reorganization of the right's agenda after the peak of the Pink Wave around 2008. At this time Venezuela, Argentina, Brazil, Chile, Uruguay, Paraguay, Ecuador, Bolivia, and Nicaragua had presidents who were identified as center-left and who often acted as a regional bloc under the leadership of Hugo Chávez, which made the area the new center of emancipatory politics after the Washington Consensus.

Signs of decline appeared by the 2010s, when the global economic meltdown and the allegations of state corruption by those in power limited the political maneuvering of many presidents. As the chapter on Kirchnerism (chapter 2) mentions, the same government that was very effective in passing legislation dealing with sexuality did not support legalizing abortion, angering Argentina's supporters of reproductive rights for women. The disappointment that this caused is mild in comparison with the experience of Ecuador, a country in which Rafael Correa's Citizen Revolution rejected feminist policies and any change regarding gender and sexuality, ending in a lost decade in terms of progress on these issues. Moreover, almost all the presidents were strong men, or strong men with powerful wives, which reproduced some old practices and prejudices, such as supporting a traditional model of the family.

(C) The Author(s) 2021. Published by Cambridge University Press on behalf of Hypatia, a Nonprofit Corporation 
Evo Morales made a great difference for progressive politics in Bolivia: his policies significantly increased the number of women who own land, for example; but in 2015, he angered supporters when he commented that he did not want to think that his health minister, a single woman, was a lesbian. ${ }^{1}$ A year later, though, his party, MAS, helped to pass new legislation that permitted the change of gender on official identification documents, following what had been done in Argentina, Uruguay, and Colombia. Regardless, Christian organizations pressured for changes in some articles of the law, and the definition of marriage and family remained the same. Elisabeth Jay Friedman has organized this book to help us to understand the contradictory political dynamics of countries like Bolivia. Accounts of the mixed results achieved by these governments appear throughout this book, and after reading it one might feel overwhelmed by the failures of a process that started as transformative only to end engulfed in accusations of corruption and dictatorial rule in Nicaragua, a humanitarian crisis in the case of Venezuela, the victories of the right in Chile and Argentina, the end of Correa's government in 2017, and the emergence of the evangelical presidents Jair Bolsonaro and Jeanine Áñez in Brazil and Bolivia, both supporting an explicit antifeminist, anti-LGBT agenda.

Against this pessimistic wave, we need to take a good look at what happened and the reasons for both the successes and failures of this movement, which is what this book offers; this is a superb comparative study of how the Pink Tide's leadership engaged with the existing demands of feminist, women's, lesbian, gay, bisexual, and transgender (LGTB) organizations. Leftist coalitions took on these issues mostly because by the end of the twentieth century strong organizations were well prepared politically through the fights and resistance of the 1980s and 90s. In addition, the importance that human rights acquired after the end of the dictatorships that dominated Latin America from the 1960 s to the 80 s had enabled an honest debate about the meaning of tolerance, inclusion, and human rights in many countries.

Another important lesson of this book is that we need to pay attention to context and avoid short-term analysis; after all, the return to hard neoliberalism in Argentina was short-lived, and President Macri lost the last election to a center-left coalition organized by Kirchnerism in 2019. This is a reminder that neoliberal economic policies, in any of its incarnations, have always encountered great resistance that helped to rebuild progressive coalitions, usually after a socioeconomic crisis. Also, in this same year, the most prosperous remaining Pink Tide government ended when Morales stepped down in November, after his electoral victory led to massive protests due to allegations that the election had been fraudulent. He was replaced by a self-proclaimed interim president, the evangelical representative Jeanine Añez, the second woman to serve in this position in Bolivia's history. She represents a right-wing, religious-conservative, political alignment that made clear its difference from the previous administration when she did not include any indigenous ministers in her first cabinet, which led to accusations of racism and political discrimination.

The fortunes of Kirchner's and Morales's political movements can be better understood after reading the analysis provided by Seeking Rights, which might indicate the importance of establishing solid alliances with organizations representing women's, feminists', and LGBT interests and, at the same time, the need to avoid suffocating them through the power of the party, the leader, or the state. This is an important consideration that explains how Morales's coalition with indigenous organizations deteriorated over differences about environmental policies and the treatment of women elected to serve in government, the latter a target of harassment and violence 
throughout 2018. In spite of all the pioneering laws and policies put in place by his administration, by the 2010s critics questioned the MAS's real intentions about ending sexism and male supremacy. Morales and his close associates had accumulated so much power that many organizations felt that there was no space for action beyond him and the state he controlled.

As this study on the Pink Tide makes very clear, one problem that has not been resolved yet is how center-left parties can effectively address emancipatory demands related to gender and sexuality without imposing the needs of traditional organizations, or those of leaders who want to remain in power without term limits. It is clear that these governments made some very important gains in some countries, but in most cases also soundly failed to make a dent in the dominance of heteronormative politics that still controls Latin American countries. Another welcome contribution is the good explanation of how complex the relationships are between the state and progressive demands related to gender and sexuality; the cases presented include detailed examples of the tense relationship that exists among feminist, queer, and trans organizations when they deal with centralized state power, and also among themselves. One good example can be drawn from the collective Mujeres Creando, which was started in Bolivia in the 1990s to support a nonracist, non-Eurocentric feminist position. María Galindo is the most well-known thinker from this group; her "intuitive feminism" is linked to continuous fight and action, defending the elimination of patriarchal power and the reinvention of maternity, paternity, and the idea of the family, which made her a strong critic of Morales's accumulation of power and his intention to resolve everything though institutions that he controlled. Her idea that decolonization is not possible without the elimination of the patriarchy is influential among organizations dealing with gender and sexuality in Latin America. ${ }^{2}$

Unlike other editions that offer disjointed articles that do not always blend well, this is a coherent project, well-conceived and argued. It also provides an excellent introduction, written by Friedman and Constanza Tabbush, that carefully connects the topics addressed, their importance, and their links with each chapter. It is a very helpful map for recognizing the main forces and issues that defined gender and sexuality in the first two decades of the twenty-first century. I appreciate how Friedman was able to bring together scholars from different countries, new voices that are not always found in books about Latin America published in the United States. I would recommend this book for any upper-division undergraduate or graduate seminar about gender and sexuality. Assigning the whole book might be overwhelming for those who have no knowledge of this area at all, but this is a problem that can be solved by picking carefully some of the cases included and providing clear context on how to read them.

Seeking Rights is a very helpful tool for teaching comparative politics and intersectionality because it studies the complex coalitions that were created to change the traditional ideas about gender and sexuality. For example, the analysis of the Frente Amplio in Uruguay indicates the significant gains, in both feminist and sexual diversity agendas, achieved during its years in power. Also, it indicates how "on occasion some feminist demands have been directly rejected or more subtly resisted by powerful actors within the Left" (75). The blocking of abortion legislation by leaders of the Left "raises questions about the strength of the commitment" to passing transformative laws (35). Edurne Larracoechea Bohigas's chapter on Nicaragua demonstrates how at the same time that trans women participate in the Miss Gay competition sponsored by Ortega's government, their identity is not officially recognized by a state that defends traditional family values (chapter 7). The same can be said about Rachel Elfenbein's 
account of the Bolivarian revolution in Venezuela, a fascinating case in which the government's promotion of feminist socialism hid the fact that the redistribution of productive and reproductive labor did not change what women experienced under neoliberal policies (chapter 6).

Finally, the book argues its case so effectively that it provides possible links for future investigation; for example, although there is plenty of emphasis on the Catholic Church in many chapters, less attention is paid to the evangelical movement that is growing politically in Latin America, even in Cuba. Approximately twenty percent of the population of Latin America follows evangelical pastors and have abandoned Catholicism. It is true that the religious right finds all Christians united around issues like abortion and gay marriage, but it is also a fact that the role of Catholic priests and evangelical pastors in the political process have important historical differences besides their competition for the same population of followers. Liberation and prosperity theologies can both be Christian, but they introduce opposite interpretations of the role of religion in society, for example. It is estimated that by 2022, Brazilian Catholics will be a religious minority, and in Bolivia, evangelicals have grown by almost ten percentage points, from $7.6 \%$ in 1985 to $17 \%$ today, which was reflected in their success confronting Morales. ${ }^{3}$ Obviously, at the time this book was planned, Bolsonaro was not president of Brazil, and Añez had not linked the fate of her country to the supremacy of the Bible, but now that we have examples of how Pentecostals and prosperity theology organize political alliances to gain power, we can analyze the impact that they have in gender and sexuality politics.

Another important topic included in Seeking Rights is reproductive health, and it is important to continue research to determine how indigenous women's organizations deal with family-planning programs. The different articles do not recognize that for indigenous populations giving birth is not related exclusively to having material resources; by itself their reproduction challenges the policies of extermination and depopulation that had always defined their existence, and, more importantly, reproduction allows the continuation of their communities. If we examine the work of Hilaria Supa Huamán, a Peruvian human-rights activist and a congresswoman from 2006 to 2011, we can see how she denounced Alberto Fujimori's family-planning program because it was used to sterilize hundreds of indigenous women. Women's reproductive rights can be manipulated, in this case by a right-wing politician, Alberto Fujimori, who managed to appear more politically progressive while delivering his speech at the 1995 Fourth Women's Conference in Beijing. ${ }^{4} \mathrm{He}$ was the only male head of state invited to speak because of his support of women's reproductive rights and a family-planning policy supported by international aid; but in fact this plan ended up sterilizing women without their consent as a way to decrease the number of poor people and, more important, the indigenous population. At stake is the legitimacy of establishing policies to limit reproduction among indigenous women without taking into consideration that this has often been the goal behind many exploitative and oppressive practices of Latin American governments. ${ }^{5}$

Lastly, although Cuba is not included in this volume, it is important to consider that it returned to political prominence in Latin America because of the Pink Tide governments, such as Chavez's. Cuba took on issues related to gender and sexuality from this new context, and Mariela Castro, head of Cuba's National Center for Sexual Education (CENESEX), became an important voice for LGBT rights in Latin America, an image that softened the extremely homophobic Cuban Revolution's past. ${ }^{6}$ As in the other countries, though, the results of this attempt are mixed. In 2018 the goal to include 
gay marriage in the constitution failed partly because of the campaign organized by evangelicals and Catholics, and last year the Cuban government canceled a parade against homophobia, raising accusations about the CENESEX's "pink-washing."7 These comments illustrate how many roads Seeking Rights opens, and how it provides a solid foundation for future research, which in itself is one of its greatest achievements.

\section{Notes}

1 The incident was reported internationally; see Molina 2015.

2 For a definition of "feminismo bastardo," see Mujeres Creando 2020.

3 For a study of the growth of evangelical churches, see Alves 2017; Casey 2019.

4 See Stavig 2017 for a discussion of the political development of this policy.

5 See the translation of Huamán's book: Huamán 2008.

6 Abel Sierra Madero has written extensively about sexuality in Cuba. For example, see Madero 2016.

7 The accusations of pink-washing have increased in the last five years. See Fiol-Matta 2016; Browne 2018.

\section{References}

Alves, J. E., S. Cavenaghi, L. F. Barros, and A. A. D. Carvalho. 2017. Distribuição espacial da transição religiosa no Brasil. Tempo Social 29 (2): 215-42.

Browne, Evie. 2018. Same sex-marriage: Is Cuba using it to "pinkwash" other oppressive policies? The Conversation, November 20. https://theconversation.com/same-sex-marriage-is-cuba-using-it-to-pinkwash-other-oppressive-policies-107018.

Casey, Matthew Peter. 2019. Old religious tensions resurge in Bolivia after ouster of longtime indigenous president. The Conversation, November 19. https://theconversation.com/old-religious-tensions-resurgein-bolivia-after-ouster-of-longtime-indigenous-president-127000.

Fiol-Matta, Lycia. 2016. Queer/sexualities. In Critical terms in Caribbean and Latin American thought: New directions in Latino American cultures, ed. Y. Martínez-San Miguel, B. Sifuentes-Jáuregui, and M. Belausteguigoitia. New York: Palgrave Macmillan.

Laclau, Ernesto. 2005. On Populist Reason. London: Verso.

Madero, Abel Sierra. 2016. Academias para producir machos en Cuba. Letras libres (January). https://www. letraslibres.com/sites/default/files/files6/files/convivio-sierra-mex.pdf.

Molina, Fernando. 2015. Bolivia’s Morales apologizes for homophobic remark about minister. El País, November 18. https://english.elpais.com/elpais/2015/11/18/inenglish/1447850199_691801.html.

Mujeres Creando 2020. Feminismo bastardo: Entrevista a María Galindo. reVISTA 2, May 17. http://mujerescreando.org/feminismo-bastardo-entrevista-a-maria-galindo-por-re-vista/.

Stavig, L. I. 2017. Feminist assemblages: Peruvian feminisms, forced sterilization, and paradox of rights in Fujimori's Peru. M. A. dissertation, Lethbridge, Alta: University of Lethbridge, Department of Anthropology.

Supa Huamán, Hilaria. 2008. Threads of my life: The story of Hilaria Supa Huamán, a rural Quechua woman. Pendicton, B.C.: Theytus Books.

Adriana Novoa is a cultural historian whose specialty is science in Latin America. With Alex Levine, she has written two books about Darwinism in Argentina: From Man to Ape: Darwinism in Argentina, 18701920 (University of Chicago Press) and ¡Darwinistas! The Construction of Evolutionary Thought in Nineteenth-Century Argentina (Brill). She is currently completing another manuscript on this topic, which treats the politics of evolutionism and its relationship to gender and race: "From Virile to Sterile: Masculinity and National Identity in Argentina." Dr. Novoa's articles have been published in Journal of Latin American Studies, Science in Context, The Latinoamericanist, Cuban Studies, Revista Hispánica Moderna, and Perspectives in Science, among others. 